\title{
Technical Knowledge in a Technical Society: Elementary School Technology Education in Sweden, 1919-1928
}

\author{
Jonas Hallström
}

\section{Linköping University Post Print}

\section{Tweet}

N.B.: When citing this work, cite the original article.

This is an electronic version of an article published in:

Jonas Hallström, Technical Knowledge in a Technical Society: Elementary School Technology Education in Sweden, 1919-1928, 2009, History of Education, (38), 4, 455-474. History of Education is available online at informaworldTM:

http://dx.doi.org/10.1080/00467600801995427

Copyright: Taylor \& Francis (Routledge): SSH Titles http://www.routledge.com/

Postprint available at: Linköping University Electronic Press http://urn.kb.se/resolve?urn=urn:nbn:se:liu:diva-51457 


\title{
Technical Knowledge in a Technical Society: Elementary School Technology Education in Sweden, 1919-1928
}

\author{
Jonas Hallström \\ Department of Behavioural Sciences and Learning \\ Linköping University \\ Linköping, Sweden
}

The aim of this article is to identify a technical domain of knowledge in the curriculum of the Swedish elementary school and views on elementary school technology of two interest groups - school teachers and engineers. Gradually during the early to mid1920s there was an increased technical content in the Swedish elementary school, if we look at the new curriculum, in-service education and stakeholders' views. The main reasons for this were, first of all, that the first decades of the twentieth century witnessed industrial growth with accompanying technification of large parts of society including the school. Secondly, the curriculum of 1919 had a broader technical content than earlier curricula, and thus mirrored the societal changes. Thirdly, vocational secondary schools led to new requirements on elementary technology education. Representatives of the Government were prime movers in enhancing the significance of technology in school together with teachers, while engineers generally showed little interest.

Keywords: educational reform, history, schoolteacher, science 
[M]odernity took on a distinctly Swedish style in which technological progress was to be accepted as the great equalizer, the main source of both economic growth and social welfare. $^{1}$

In the period from 1900 to the 1920s Sweden was transformed from an agricultural country to an industrial one. In this process the Swedish population was also growing rapidly and society was being urbanized. ${ }^{2}$ Technology played a central part in the major industrial and economic development, partly because exploitation of natural resources such as iron ore deposits and waterfalls required technology, partly as a few large engineering firms became prime exporters of Swedish innovations. ${ }^{3}$ In 1900 to 1920 there was also a widespread extension of technological systems such as railroads, tramways, water supply and sewerage, telephone lines and electric grids. The latter spurred the spread of new household technologies such as electric irons, vacuum cleaners and stoves in the early 1920s. The internal combustion engine and electricity also began to revolutionize agriculture as well as road and air transport, and towards the mid-1920s radio broadcasting commenced. ${ }^{4}$

Due to the great industrial momentum class struggle and the forming of labour unions and employers' associations intensified in the beginning of the twentieth century, but in 1918 to 1921 universal suffrage was introduced and a less conflict-ridden period ensued. ${ }^{5}$ Parallel to

\footnotetext{
${ }^{1}$ Aant Elzinga, Andrew Jamison and Conny Mithander, 'Swedish Grandeur: Contending Reformulations of the Great-Power Project', in The Intellectual Appropriation of Technology: Discourses on Modernity, 1900-1939, ed. Mikael Hård and Andrew Jamison (Cambridge, MA \& London: The MIT Press, 1998), 133. The research on which this article is based has also partly provided material for Jonas Hallström, 'Elementary School Technology Education in Sweden, ca. 1900-1920', in PATT 18, Pupils' Attitudes Towards Technology, International Conference on Design and Technology Educational Research 2007, Teaching and Learning Technological Literacy in the Classroom, ed. John R. Dakers, Wendy J. Dow and Marc J. de Vries (Glasgow: Faculty of Education, University of Glasgow, 2007).

${ }^{2}$ Gunnar Richardson, Svensk utbildningshistoria. Skola och samhälle förr och nu, 6th ed. (Lund: Studentlitteratur, 1999), 59-72; Rune Bokholm, Städernas handlingsfrihet: En studie av expansionsskedet 19001930 (Lund: Lund University Press, 1995), 290-294.

${ }^{3}$ Boel Berner, 'Professional or Wage Worker? Engineers and Economic Transformation in Sweden', in Engineering Labour: Technical Workers in Comparative Perspective, ed. Peter Meiksins and Chris Smith (London \& New York: Verso, 1996), 173-174.

${ }^{4}$ See, for example, Staffan Hansson, Den skapande människan. Om människan och tekniken under 5000 år (Lund: Studentlitteratur, 2002), 411-423, 430-433; Jonas Hallström, Constructing a Pipe-Bound City: A History of Water Supply, Sewerage, and Excreta Removal in Norrköping and Linköping, Sweden, 1860-1910 (Linköping: Dept. of Water and Environmental Studies, Linköping University, 2002), 301-334; Jan-Erik Hagberg, Tekniken $i$ kvinnornas händer. Hushållsarbete och hushållsteknik under tjugo- och trettiotalen (Linköping/Malmö: Universitetet i Linköping, Institutionen för Tema, Teknik och social förändring/LiberFörlag, 1986), 32-61; Janken Myrdal and Mats Morell, 'Fodertäkt, skörd och tröskning', in Agrarhistoria, ed. Bengt M P Larsson, Mats Morell and Janken Myrdal (Stockholm: Natur och Kultur, 1997), 158-165; and Nina Wormbs, Genom tråd och eter. Framväxten av distributionsnätet för radio och TV (Stockholm: Stiftelsen etermedierna i Sverige, 1997), 23-34.

${ }^{5}$ Lars Magnusson, Sveriges ekonomiska historia (Stockholm: Rabén Prisma - Tiden Athena, 1996), 389-392. In this article I consider the introduction of universal suffrage as the single most important aspect of democratization.
} 
the processes of industrialization and democratization there was also an intense period of educational reform, the outcome of which was a modern elementary school curriculum and new vocational schools. The Swedish elementary school - folkskola, the traditional school of the people - and the teaching of its different subjects were thereby affected by the current societal transformation.

This article follows the societal transformation into the 1920s, which was before technology was established as an individual school subject. Nevertheless, this period was important in that technological knowledge existed in other subjects and that the demands for a technical content in elementary school increased. In a sense, therefore, this period illuminates the pre-history of modern Swedish school technology, introduced as a voluntary subject in the 1960s and an obligatory subject in the early 1980s (Teknik). ${ }^{6}$ Historical research concerning the origins of technology education in schools has been missing to a great extent in the fields of technology education as well as history of education and curriculum history, particularly for countries other than the United States. ${ }^{7}$ Historians of technology have shown interest in

\footnotetext{
${ }^{6}$ Ulla Riis, 'Kan man äga ett skolämne - dragkampen om tekniken', in Teknik i skolan. Perspektiv på teknikämnet och tekniken, ed. Thomas Ginner and Gunilla Mattsson (Lund: Studentlitteratur, 1996).

${ }^{7}$ For example, W. B. Waetjen, 'Shaping the Future of a Profession', in Critical Issues in Technology Education (Reston, VA: International Technology Education Association, 1992); John R. Pannabecker, 'Diderot, the Mechanical Arts, and the Encyclopédie: In Search of the Heritage of Technology Education', Journal of Technology Education 6, no. 1 (1994): 45-57; and Jan-Erik Hagberg and Magnus Hultén, Skolans undervisning och elevers lärande i teknik. Svensk forskning i internationell kontext (Stockholm: Vetenskapsrådet, 2005) have pointed to the scarcity of historical research on technology in schools. However, quite a few articles and reports have been written on the history of American industrial arts and technology education, such as Patrick N. Foster, 'The Founders of Industrial Arts in the US', Journal of Technology Education 7, no. 1 (1995); Dennis R. Herschbach, "'What Is Past Is Prologue": Industrial Arts and Technology Education', Journal of Technology Studies 22, no. 1 (1996): 28-39; Dennis R. Herschbach, 'From Industrial Arts to Technology Education: The Search for Direction', Journal of Technology Studies 23, no. 1 (1997): 24-32; Dennis R. Herschbach, 'From Industrial Arts to Technology Education: The Eclipse of Purpose', Journal of Technology Studies 23, no. 2 (1997): 20-8; Karen F. Zuga, 'An Analysis of Technology Education in the United States Based Upon an Historical Overview and Review of Contemporary Curriculum Research', International Journal of Technology and Design Education 7, no. 3 (1997): 203-17; and Theodore Lewis and Karen F. Zuga, A Conceptual Framework of Ideas and Issues in Technology Education (Arlington, VA: Technology Teacher In-service Education \& National Science Foundation, 2005), http://www.coe.uga.edu/ttie/documents/CF_Total.pdf (accessed October 23, 2006). Gary McCulloch, Edgar Jenkins and David Layton, Technological Revolution? The Politics of School Science and Technology in England and Wales Since 1945 (London, Falmer Press, 1985) deals with the post-war situation in England and Wales, and David Layton, ed., Innovations in Science and Technology Education Vol. V (Paris: UNESCO Publishing, 1994) contains a few historical flashbacks from different parts of the world. Sven G. Hartman, Hans Thorbjörnsson, and Eva Trotzig, Handens pedagogik. Kulturarv och utveckling i skolslöjden (Linköping: Skapande Vetande, Linköpings universitet, 1995) and Sven G. Hartman, Det pedagogiska kulturarvet. Traditioner och idéer i svensk undervisningshistoria (Stockholm: Natur och kultur, 2005) outline the historical roots of educational sloyd in Sweden. John R. Pannabecker, 'Inventing Industrial Education: The Ecole D'arts Et Métiers of Châlons-Sur-Marne, 1807-1830', History of Education Quarterly 44, no. 2 (2004), http://www.historycooperative.org/journals/heq/44.2/pannabecker.html (accessed January 17, 2006) explores the older roots of technology education in Europe, while Marc J. de Vries and Ilja Mottier, ed., International Handbook of Technology Education: Reviewing the Past Twenty Years (Rotterdam \& Taipei: Sense Publishers, 2006) examines the last twenty years of technology education in many parts of the world.
} 
education, but this has mainly been studies of higher engineering education or museums where curricula or teaching have played only a minor role. ${ }^{8}$

The aim of this article is therefore to identify a technical domain of knowledge in the curriculum of the Swedish elementary school as well as views on elementary school technology of central interest groups, from 1919 to 1928 . The source material is the Swedish elementary school curriculum of $1919^{9}$ as well as school- and technology-oriented journals in connection with this curricular change and all but throughout the $1920 \mathrm{~s}:{ }^{10}$ Svensk Läraretidning, journal of the Swedish Association of Elementary School Teachers (Sveriges allmänna folkskollärarförening) as well as Teknisk Tidskrift, ${ }^{11}$ journal of the Swedish Association of Graduate Engineers (Svenska Teknologföreningen). ${ }^{12}$

Theoretically, this article is inspired by an approach to the study of technology education put forward by David Layton, who sees the evolution of technology education as a negotiation between different stakeholders or interest groups. School technology is subject to 'a range of competing influences' and it is possible to pinpoint the 'principal actors in this curriculum

\footnotetext{
${ }^{8}$ Stephen Petrina, 'Sidney Pressey and the Automation of Education, 1924-1934', Technology and Culture 45, no. 2 (2004): 305-7; Bosse Sundin, 'Inledning: Temanummer teknikhistoria', Historisk tidskrift 119, no. 3 (1999): 353-70. In recent years a few historians of education have written about technical museums and exhibitions from a more pedagogical point of view, for example, Kathleen M. Fennessy, "'Making Difficult Things Plain": Learning at the Industrial and Technological Museum, Melbourne, 1870-1880', History of Education Review 34, no. 2 (2005): 59-77 and Joanne Scott, 'Mechanical Contrivances and Fancy Needlework: The Brisbane Exhibition and Education in Colonial Queensland', History of Education Review 36, no. 1 (2007).

${ }^{9}$ The Swedish undervisningsplan and läroplan constituted official documents that prescribed the content and goals for the Swedish school and the different subjects, much as the German Lehrplan. Although the English word curriculum is broader than the Swedish word it will be used for want of a better term. Cf. Ulf P. Lundgren, Att organisera omvärlden. En introduktion till läroplansteori (Stockholm: Liber, 1989), 19-23.

${ }^{10}$ The choice of 1919-1928 as the ten-year period of investigation is motivated by several important changes to the Swedish school system. In 1918 an investigation of the role of elementary school in the whole educational system (1918 års skolkommission) was appointed and new vocational schools on secondary level (praktiska ungdomsskolor) were launched. 1919 was the year the elementary school curriculum came. In 1927 the above investigation and other work resulted in a new organization of and curriculum for secondary school. A first evaluation of the 1919 curriculum was also finished in 1927-1928: Viktor Fredriksson, Lars Hofstedt, and Sigurd Paradis, Svenska folkskolans historia, femte delen. Det svenska folkundervisningsväsendet 1920-1942 (Stockholm: Bonniers, 1950), 136-150, 435-440.

${ }^{11}$ The journal Teknisk Tidskrift was divided into a general section, Allmänna avdelningen (periodically also called Veckoupplagan), and several specialized sections that represented different areas of the engineering sciences. I have limited my research to the general section, since this was where educational matters were mostly discussed.

${ }^{12}$ Elementary school teachers and engineers - the former representing elementary school itself and the latter engineering, trade and industrial interests - are thought to have had different stakes in elementary technical schooling. The teachers taught most or all school subjects, but were not necessarily interested in technology, while the engineers had an interest in technological and industrial advance but not necessarily elementary education. In the following analysis the views put forward in their respective journals are seen as official, sanctioned views of the whole group, since the writers were often closely connected to the associations and the journals were seen as official mouthpieces. This is not to say that there were no diverging interests within these two groups, but I choose to focus on views that were supposedly representative of a majority in order to contrast the different stakeholders: David Layton, 'A School Subject in the Making? The Search for Fundamentals', in Innovations in Science and Technology Education Vol. V, ed. David Layton (Paris: UNESCO Publishing, 1994); Fredriksson, Hofstedt, and Paradis, Svenska Folkskolans Historia, Femte Delen, 386-389. Cf. Peter Burke, History and Social Theory (Cambridge: Polity Press, 1992), 28.
} 
drama' ${ }^{13}$ Ivor F. Goodson argues similarly that 'subjects are not monolithic entities but shifting amalgamations of subgroups and traditions which through contestation and compromise influence the direction of change.... the debate over curriculum can be interpreted in terms of conflict between subjects over status, resources and territory. ${ }^{, 14}$ Furthermore, there is a social conflict aspect to the forming of any school subject, and this is especially true of technology education. ${ }^{15}$

In this article views on Swedish elementary school technology are focussed, and especially Layton's approach will be used as a framework for analysis. ${ }^{16}$ Layton identifies several, somewhat idealized stakeholders that can influence the making of technology curricula. While his categorization primarily applies to the 1990s and is mainly concerned with a curriculum in the making, I believe that it could at least partially be employed in a historical situation - the 1920s - and the aftermath of a curriculum. After all, the backwash of a new curriculum also constitutes the prelude to new curricular discussions and changes. I will use four of Layton's categories as a way of sorting out competing ideological influences on stakeholders: economic instrumentalists, professional technologists, girls and women and defenders of participatory democracy. These categories are wide enough to translate into the context of the 1920s. The ideologies of the two former stakeholders dominated the Swedish public discourse, while those of the two latter increasingly gained ground as a result of democratization. $^{17}$

The object is also to pinpoint a technical knowledge domain. The definition of technology (in Swedish, teknik) that will be used in the current article is adapted from Ginner (1996): Technology is everything that humans put between themselves and their environment in order to fulfil different needs as well as the knowledge and skills that they develop and manage in this problem-solving process. ${ }^{18}$ Technology stems from a practical knowledge tradition. In

\footnotetext{
${ }^{13}$ Layton, 'A School Subject in the Making?', 11-9. Cf. David Layton, Science for the People: The Origins of the School Science Curriculum in England (London: George Allen \& Unwin Ltd, 1973), 7-8.

${ }^{14}$ Ivor F. Goodson, Studying Curriculum: Cases and Methods (Buckingham: Open University Press, 1994$), 42$.

${ }^{15}$ Ivor F. Goodson, Learning, Curriculum and Life Politics: The Selected Works of Ivor F. Goodson (London \& New York: Routledge, 2005), 69-70.

${ }^{16}$ The method employed in this study is a hermeneutic method, that is, a method of interpretation. The stance put forward is historicist, that is, meaning is determined by the context in which the source material was written as well as the historian's own context: Burke, History and Social Theory, 17-21; Ian MacLean, 'Reading and Interpretation', in Modern Literary Theory: A Comparative Introduction, ed. Ann Jefferson and David Robey, 2nd ed. (London: B. T. Batsford, 1986), 122-124, 136-138. Cf. Gary McCulloch and Ruth Watts, 'Introduction: Theory, Methodology, and the History of Education', History of Education 32, no. 2 (2003): 129-32.

${ }^{17}$ Layton, 'A School Subject in the Making?', 13-18. Layton also identifies sustainable developers and liberal educators as stakeholders in the 1990s.

${ }^{18}$ Thomas Ginner, 'Teknik som skolämne', in Teknik $i$ skolan. Perspektiv på teknikämnet och tekniken, ed. Thomas Ginner and Gunilla Mattsson (Lund: Studentlitteratur, 1996), 18-28. Cf. Svante Lindqvist, 'Vad är teknik?', in I teknikens backspegel. Antologi i teknikhistoria, ed. Boel Berner and Bosse Sundin (Stockholm:
} 
fact, in line with David E. Nye we can say that technology is so integral to human culture and society that it has preceded any form of text production and theorizing. ${ }^{19}$ However, throughout history technology has also been theorized, and theoretical influences from the natural sciences increasingly pervaded it from the nineteenth century onward. Knowledge about technology therefore includes both practical and theoretical aspects, although these are different in nature. ${ }^{20}$ Edwin T. Layton puts this succinctly: 'We may view technology as a spectrum, with ideas at one end and techniques and things at the other ...,21

\section{Swedish technical education in the nineteenth and early twentieth centuries}

Around 1800 European technology education was military and government controlled, for example, in France, Austria and even in Sweden. Modern and highly qualified technology education came with industrialization, however. Towards the mid-nineteenth century, the dawn of Swedish industrialization, ideas occurred of how to divide Swedish technology education into different levels. According to Rolf Torstendahl, up to 1870 three levels had crystallized. The Technological Institute, later to become the Royal Institute of Technology (Kungliga tekniska högskolan, KTH), and Chalmers' Sloyd School constituted the highest level; higher education which was also science oriented. In the rising Swedish industry there was a need for theoretically trained engineers and designers in leading positions, but also more practical engineers with qualities of leadership such as master mechanics and foremen. It seems that in Sweden and the other Scandinavian countries higher engineering schools were modelled primarily on corresponding Austrian and German schools, which had been integral to industrialization in Central Europe. ${ }^{22}$

\footnotetext{
Carlssons, 1987), 11-33 and Stephen J. Kline, 'What Is Technology?', in Philosophy of Technology: The Technological Condition: An Anthology, ed. Robert C. Scharff and Val Dusek (Malden, MA \& Oxford: Blackwell, 2003), 210-212.

${ }^{19}$ David E. Nye, Technology Matters: Questions to Live With (Cambridge, MA: MIT Press, 2006), 1-15.

${ }^{20}$ Sven-Eric Liedman, Ett oündligt äventyr. Om människans kunskaper (Stockholm: Bonniers, 2001), 40-45, 169-179; Elias Cornell, Byggnadstekniken. Metoder och idéer genom tiderna 2nd ed. (Stockholm: Byggförlaget, 1979), 185-200; Hansson, Den skapande människan, 231-233. Cf. Bengt Molander, Kunskap i handling (Göteborg: Daidalos, 1993), 15-34, 255-262. Marc J. de Vries argues that one fundamental thing that distinguishes technological knowledge from scientific knowledge is that it is concerned with effectiveness rather than truth: Marc J. de Vries, 'The Nature of Technological Knowledge: Philosophical Reflections and Educational Consequences', International Journal of Technology and Design Education 15, no. 2 (2005): 14954; Marc J. de Vries, Teaching About Technology: An Introduction to the Philosophy of Technology for NonPhilosophers (Dordrecht: Springer, 2005), 29-48.

${ }^{21}$ Edwin T. Layton, 'Technology as Knowledge', Technology and Culture 15, no. 1 (1974): $37-8$.

${ }^{22}$ Rolf Torstendahl, Dispersion of Engineers in a Transitional Society: Swedish Technicians $1860-1940$ (Uppsala: Uppsala University, 1975), 38-43; Rolf Torstendahl, Teknologins nytta: Motiveringar för det svenska tekniska utbildningsväsendets framväxt framförda av riksdagsmän och utbildningsadministratörer 1810 -1870 (Uppsala: Historiska institutionen, Uppsala universitet, 1975), 26; Berner, 'Professional or Wage Worker?', 169-
} 
Just below this level was the so-called teknisk elementarskola - a technical school on upper secondary level, established in the 1850 s - as well as certain Sunday and evening schools. These schools educated fairly advanced engineers, for example, with future positions as foremen or assistants to university-trained engineers. On the third and lowest level were the majority of Sunday and evening schools, whose educational content varied a great deal and was not mainly technical. They educated young people for manual labour in trade and industry. The Swedish government guaranteed the quality on the two highest levels of technical education, which would yet serve both public and private, industrial interests. ${ }^{23}$

The subject-matter of this article - elementary technology education - would be just below the third of Torstendahl's levels. It thus constituted a fourth level of technology education, which was comprehensive and belonged in elementary school. This level has not really been the object of any Swedish studies so far, maybe because elementary school has not been considered a technical school or a school with any manifest technical content at all (see Figure $1)^{24}$

Up until the 1840s, the development of technical education was more or less common to sloyd education, according to Hartman et al (1995). When a more distinct structure of technology education began to appear in the mid-nineteenth century, symbolized by the three levels, it became clear that it was more occupationally oriented than sloyd. From the midnineteenth century more and more sloyd schools were established parallel to the already existing elementary schools. The first comprehensive technical education for the Swedish people can be said to have emerged around 1880, when educational sloyd was introduced as an optional subject in elementary school. ${ }^{25}$ There pupils had the opportunity to encounter and use technical tools such as saws and carpenter's benches for boys and later on also sewing machines for girls. ${ }^{26}$

179; Timo Myllyntaus, 'The Finnish Model of Technology Transfer', Economic Development and Cultural Change 38, no. 3 (1990): 634-640.

${ }^{23}$ Torstendahl, Teknologins nytta, 26; Gunnar Richardson, Tekniken, människan och samhället. Humanistiska inslag i 1940- och 1950-talens tekniska utbildning (Uppsala: Föreningen för svensk undervisningshistoria, 1987), 13; Richardson, Svensk utbildningshistoria, 51; Anders Nilsson, 'Yrkesutbildningens framväxt i Sverige fram till 1920 i ett europeiskt perspektiv', Studies in Educational Policy and Educational Philosophy, no. 3 (2005): 6-9, http://www.upi.artisan.se/ (accessed November 17, 2006).

${ }^{24}$ See Hallström, 'Elementary School Technology Education in Sweden' for a more elaborate analysis of the four levels of Swedish technology education in 1900-1920.

${ }^{25}$ This meant that it was optional for individual schools whether they wanted to offer teaching in this subject or not. The same can be said about the subjects gardening (Trädgårdsskötsel) and domestic science (Huslig ekonomi).

${ }^{26}$ Hartman, Thorbjörnsson, and Trotzig, Handens pedagogik, 19-30; Hartman, Det pedagogiska kulturarvet, 117-119, 243-245. 
The 1918 educational reform of vocational secondary schools on the third level, which had replaced, for instance, many Sunday and evening schools and now made up the level immediately above elementary school, was a victory for elementary school teachers. ${ }^{27}$ The teachers had argued for such a solution as early as the turn of the century and they played a pivotal role in seeing the reform through. The Swedish system of vocational education thus went from being largely unregulated, such as in Great Britain, to being more government controlled, much as it was in France. ${ }^{28}$

\section{The Swedish public school system in the 1920s}

In the 1920s the Swedish school was divided between several different, partly parallel educational forms, a system established since several decades. The basic distinction was between elementary/primary education - folkskola, a locally organized six-year school for the children of workers, farmers and the lower middle class - and secondary education läroverk, which was a school for middle and upper class boys organized by the Government. Secondary education was divided into two different school forms, realskola and gymnasium, chronologically following one another. Since girls were not allowed in secondary schools until 1927 private girls' schools constituted yet another form of secondary education. There was also a number of other, often locally organized, secondary schools - högre folkskola, kommunal mellanskola, fortsättningsskola - some of which were also vocational in character. $^{29}$

In the governance of the Swedish public school system there was a distinction between the Government's political and non-political administration. The Ministry of Education and Ecclesiastical Affairs (Ecklesiastikdepartementet) was the central political body, which appointed commissions, presented educational bills etc. The National Agency for Education (Skolöverstyrelsen), formed in 1920, constituted the non-political central administration,

\footnotetext{
${ }^{27}$ Vocational schools on secondary level - praktiska ungdomsskolor - were several kinds of schools gathered under the same umbrella; fortsättningsskola, högre folkskola, verkstadsskola, lärlingsskola and yrkesskola. According to the National Agency for Education there was to be a natural progression from folkskola on to fortsättningsskola, lärlingsskola and then finally yrkesskola, although this did not always happen. In some cities the old Sunday and evening schools continued their teaching, but they do not seem to have been considered a part of the public school system: Nils Fredriksson, 'De praktiska ungdomsskolorna', Teknisk tidskrift, veckoupplagan 51, no. 49 (1921): 479; 'Sambandet mellan olika skolarter', Svensk läraretidning 44, no. 7 (1925): 121.

${ }^{28}$ Ingrid Lindell, Disciplinering och yrkesutbildning. Reformarbetet bakom 1918 års praktiska ungdomsskolereform (Uppsala: Föreningen för svensk undervisningshistoria, 1992), 226-243; Nilsson, 'Yrkesutbildningens framväxt i Sverige', 16.

29 Richardson, Svensk utbildningshistoria, 59-91; Hartman, Det pedagogiska kulturarvet, 34-38, 47-54.
} 
which, for instance, executed and followed up reforms and took care of in-service education. ${ }^{30}$ Besides the two studied stakeholders the Ministry and the Agency were also central actors, although they were partly made up of representatives of the teacher and engineering interests.

Democratization influenced the Swedish school in that cries for a common, compulsory school for the children of all social classes grew stronger. The social democrat Värner Rydén was a prime mover in this question, but due to right-wing opposition and an unstable political climate with continually changing governments his efforts came to naught. Furthermore, both liberals and social democrats were divided between the defenders of a common school and proponents of an academic tradition and the parallel school system. A truly democratic school was not introduced until the 1960s. From a wider, Scandinavian perspective there was no clear connection between democratization and a 'school for all' either. Norway, for instance, initiated universal suffrage in 1913 and subsequently also a seven-year common compulsory school in 1920, while Finland was democratized as early as 1906 but did not create a compulsory school until the 1970s. ${ }^{31}$

\footnotetext{
${ }^{30}$ Sixten Marklund, Skolsverige 1950-1975. Del 3, Från Visbykompromissen till SIA (Stockholm: Liber, 1983), 91-111; Sixten Marklund, Skolsverige 1950-1975. Del 6, Rullande reform (Stockholm: Liber, 1989), 168-189; Richardson, Svensk utbildningshistoria, 192-198.

${ }^{31}$ Richardson, Svensk utbildningshistoria, 69-70; Gunnar Richardson, 'Skolan i partipolitiken', Pedagogiska Magasinet, no. 1 (2006); Jan Froestad and Bodil Ravneberg, 'Education Policy, the Norwegian Unitary School and the Social Construction of Disability', Scandinavian Journal of History 31, no. 2 (2006): 128; Tapani Kananoja, 'Technology Education in the Nordic Countries', in Innovations in Science and Technology Education Vol. V, ed. David Layton (Paris: UNESCO Publishing, 1994), 45-48; Lars-Arne Norborg and Lennart Sjöstedt, Grannländernas historia (Stockholm: Almqvist \& Wiksell, 1970), 180-190.
} 
Ca. 1900

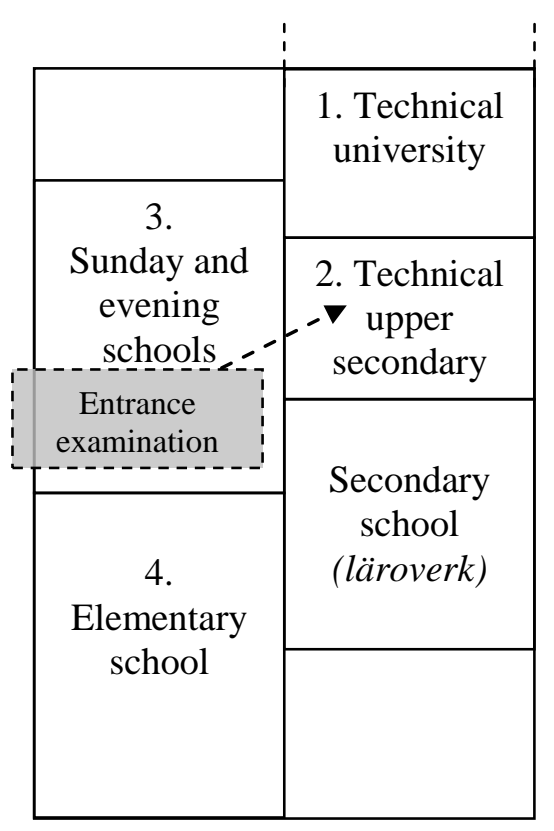

Ca. 1920

Age
\begin{tabular}{|r|}
\hline 20 \\
\hline 19 \\
\hline 18 \\
\hline 17 \\
\hline 16 \\
\hline 15 \\
\hline 14 \\
\hline 13 \\
\hline 12 \\
\hline 11 \\
\hline 10 \\
\hline 9 \\
\hline 8 \\
\hline 7 \\
\hline
\end{tabular}

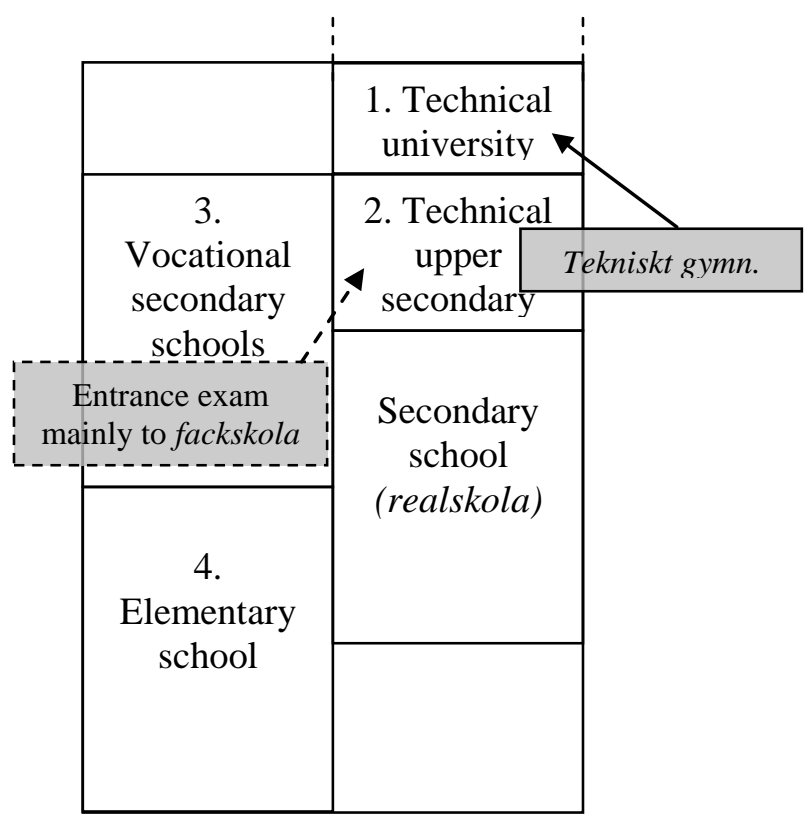

Figure 1. The four levels of Swedish technology education, ca. 1900 and 1920

Note: Rudolf Anderberg, 'Grunddragen av det svenska tekniska undervisningsväsendets historia', Teknisk tidskrift, veckoupplagan 51, no. 8, 11 (1921): 89-93, 130-4; Fredriksson, 'De praktiska ungdomsskolorna'; 'De tekniska läroverken. Tekniska föreningen och elektriska klubben i Västerås diskutera dessas organisation', Teknisk tidskrift, allmänna avdelningen 55 (1925): 221-222; SOU 1963:42; Richardson, Tekniken, människan och samhället, 13; Daniel Lövheim, Att inteckna framtiden. Läroplansdebatter gällande naturvetenskap, matematik och teknik i svenska allmänna läroverk 1900-1965 (Uppsala: Uppsala universitet, 2006), 41; Hallström, 'Elementary School Technology Education in Sweden'. 


\section{The Swedish elementary school curriculum of 1919}

The elementary school curriculum of 1919 was a mile stone in many regards; it was binding in quite another sense than earlier curricula, it clearly outlined the content and weekly hours of the different subjects and it was based on modern pedagogical research. The prevalence of the pedagogical philosophy of John Dewey was the most notable change in the latter regard. The maxim 'learning by doing' and the focus on practical work were easily recognizable in many subjects. Christianity (Kristendomsundervisning) lost its central role at the same time as, for example, the new semi-practical subject home region instruction (Hembygdsundervisning) was introduced. ${ }^{32}$ Other practical subjects such as educational sloyd and gardening (Trädgårdsskötsel) also stood out, although they were still not obligatory. ${ }^{33}$

The content of the subjects gardening and domestic science (Hushållsgöromål) had been extended compared to earlier curricula, which was both an expression of a broader content and more detailed regulation on the part of the Government. ${ }^{34}$ In the case of the former subject, plant breeding, fertilizing and spraying with pesticides had been added to the earlier practical-technical elements of digging, sowing and planting. The content of the latter, female subject had become more specified. Apart from the operation of a stove and the cleaning and management of household utensils it now also included economical fuel consumption and water management in the kitchen. ${ }^{35}$

The goal of educational sloyd was mainly to manufacture simple objects of various materials. For boys this meant all kinds of different materials, such as textiles, pasteboard, wood and metal, whereas girls had to content themselves with textiles. Boys' sloyd emphasized the preparation, use and keeping of tools. The tools could be vices, anvils, screwdrivers, files, drills, planes, chisels, riveting and soldering equipment. Certain elements had also been mechanized, for instance, turning. In girls' sloyd tools did not attract as much attention. It was instead various kinds of sewing techniques that were focused. Nonetheless, technical development left its mark on the curriculum in that the sewing machine earned a central place, but not until the girls had learnt the basic manual sewing techniques. In this

\footnotetext{
${ }^{32}$ Home region instruction is a fairly literal translation of hembygdsundervisning. In some dictionaries it is translated as local geography, since there was a clear connection to the geography subject in that the first two or three years of elementary geography education should take place within the confines of hembygdsundervisning. However, otherwise geography education was very oriented towards natural geography - except for a few cultural geography items such as means of transport, working life and major cities, which were more developed in home region instruction - which is why the geography subject has not been included in the study.

${ }^{33}$ Fredriksson, Hofstedt, and Paradis, Svenska folkskolans historia, femte delen, 414-428; Hartman, Det pedagogiska kulturarvet, 47-49, 223-235.

${ }^{34}$ See Hallström, 'Elementary School Technology Education in Sweden', 21-26 for an analysis of the earlier curricula.

${ }^{35}$ Undervisningsplan för rikets folkskolor, den 31 Oktober 1919 (Stockholm 1947), 134-136, 146-148.
} 
respect, there was more mechanization and a more substantial technical transformation for the girls. $^{36}$

Natural science was also described in more detail than before, and there was an even stronger emphasis on the technical applications of physical and chemical phenomena - the pump, the steam engine, the telegraph and the telephone. The breakthrough for electricity was particularly noticeable: 'Something about the characteristics of fluids and gases, about the equilibrium and motion of solids, about water and steam as driving force, about magnetism as well as electricity and its most important practical applications. ${ }^{37}$ The higher grades should bring up these features in such a way that 'above all, physical and chemical phenomena are seen from the point of view of their significance for practical life. 38

Drawing can also be said to have been part of a technical domain, and this subject had been enlarged as regards content and attention to detail compared to the previous curriculum. The focus on practical life outside school remained, but this curriculum also attached great weight to pupils' activity, which was a central theme in all subjects. Drawing was connected more clearly to sloyd, and it also looked ahead to possible future technology education, at least for boys: 'Linear drawing: for boys: projection drawing of elementary furniture and tools etc.'39

The new interdisciplinary subject home region instruction was very likely inspired by Dewey, both his philosophy and the teaching practice of his experimental school in Chicago, ${ }^{40}$ while it also reflected nationalist undercurrents: ${ }^{41}$ 'Home region instruction intends . . to give basic teaching in geography and natural science as well as history, to some extent, furthermore ... to provide preparatory teaching in drawing and sloyd. ${ }^{42}$ Examples of technical content in home region instruction were clothes, different kinds of materials, houses and their heating and lighting, furniture and household utensils, transport technology ('different ways of travelling') as well as working life such as agriculture, trade and industry. The subject should focus humans and nature in the local environment, but in cities it was evident that the emphasis would be on human activities and the designed world. Practical

\footnotetext{
${ }^{36}$ Undervisningsplan för rikets folkskolor, den 31 Oktober 1919 (Stockholm 1947), 137-145.

${ }^{37}$ Undervisningsplan för rikets folkskolor, den 31 Oktober 1919 (Stockholm 1947), 85. All translation from Swedish into English has been carried out by the author.

${ }^{38}$ Undervisningsplan för rikets folkskolor, den 31 Oktober 1919 (Stockholm 1947), 100.

${ }^{39}$ Undervisningsplan för rikets folkskolor, den 31 Oktober 1919 (Stockholm 1947), 58-69, 110-118 (quote on p. 111).

${ }^{40}$ See, for example, John Dewey, The School and Society and the Child and the Curriculum (Chicago \& London: The University of Chicago Press, 1990), 163-178; John Dewey, Democracy and Education (Mineola, NY: Dover Publications, 2004), 198-209.

${ }^{41}$ Elzinga, Jamison and Mithander, 'Swedish Grandeur', 129-140.

${ }^{42}$ Undervisningsplan för rikets folkskolor, den 31 Oktober 1919 (Stockholm 1947), 70.
} 
exercises such as modelling were also included and these linked up with similar exercises in both sloyd and drawing. ${ }^{43}$

\section{Stakeholder views of Swedish school technology education in the 1920s}

In the following section stakeholder views on technology education in elementary school will be presented both chronologically and thematically. Neither of the studied journals made reference to the technical content of elementary school subjects in direct connection with the 1919 curriculum. Regarding sloyd, for example, it was often emphasized in Svensk Läraretidning that it developed the pupils' 'spiritual and bodily powers' in a comprehensive way, rather than communicating technical knowledge and preparing for a profession. ${ }^{44}$ Sloyd was therefore a subject aimed more at instilling practical, comprehensive knowledge (allmänbildning) ${ }^{45}$ than specific technical skills, which, according to Hartman et al (1995), was typical of Swedish educational sloyd in the period from 1880 to $1920 .^{46}$

\section{The Swedish Association of Elementary School Teachers (Svensk Läraretidning)}

A few years later, however, another picture emerged, if we look at in what ways elementary school teachers were themselves further educated to improve their teaching. In Svensk Läraretidning there was a short paragraph on this in 1922:

This is a transition period for our elementary school. The societal mission of elementary school is expanding and growing, which, not the least, the teachers have to sustain. 'Increase your knowledge' is the watchword for the individual teacher as well as the whole profession. ${ }^{47}$

\footnotetext{
${ }^{43}$ Undervisningsplan för rikets folkskolor, den 31 Oktober 1919 (Stockholm 1947), 70-79.

${ }^{44}$ See, for instance, 'Om slöjdundervisning för gossar. Föredrag av undervisningsrådet Hjalmar Berg', Svensk Läraretidning 41, no. 18 (1922): 343 and Gunnar Nilsson, 'Om Slöjdundervisningen', Svensk Läraretidning 41, no. 21 (1922): 397-8.

${ }^{45}$ Allmänbildning - or merely bildning - were derived from the German word Bildung, meaning comprehensive, all-round knowledge that fundamentally transforms human beings into becoming mature, independent citizens. The closest English translation would be general education or liberal education, but these concepts do not quite convey the full meaning of the Swedish terms: Liedman, Ett oändligt äventyr, 350-355; Sten Högnäs, 'The Concept of Bildung and the Education of the Citizen: Traits and Developments in the Nordic Countries 18702000', in Nordic Lights: Education for Nation and Civic Society in the Nordic Countries, 1850-2000, ed. Sirkka Ahonen and Jukka Rantala (Helsinki: Finnish Literature Society, 2001), 29-31. Cf. Bernt Gustavsson, Bildning i vår tid. Om bildningens möjligheter och villkor i det moderna samhället (Stockholm: Wahlström \& Widstrand, 1996), 13-35.

${ }^{46}$ Hartman, Thorbjörnsson, and Trotzig, Handens pedagogik, 32-36.

${ }^{47}$ 'Kursen i metallindustri och elektroteknik i Västerås', Svensk Läraretidning 41, no. 34 (1922): 661.
} 
The knowledge in question here was technical knowledge. In the summer of 1922 the National Agency for Education consequently offered a course for elementary school teachers from the whole country in industrial metallurgy, electro-technology, chemistry and drawing. ${ }^{48}$ In 1923, a summer course in physics for elementary school teachers was held at Göteborg University. It included primarily electricity and the building of electric appliances. ${ }^{49}$

In 1925 Sven Nylund of the National Agency for Education made a speech that was published in its entirety in Svensk Läraretidning - 'Elementary school in our time'. Among several other things he stressed the increased significance of elementary school now that the vocational secondary schools were so clearly built upon it, something which his colleague Nils Fredriksson also emphasized (see below). Furthermore, a great many Swedish children would only get the 'bookish and practical knowledge [praktisk bildning]' that elementary school provided. Nylund particularly focused on scientific and technical knowledge: ${ }^{50}$

\footnotetext{
Modern agriculture with accompanying stock and dairy farming, which are nowadays more mechanized (motorized, electrified) and on a scientific foundation ..., place completely different demands on . . . the workers' comprehensive knowledge [allmänbildning] and specialist knowledge than in times past. ${ }^{51}$
}

In the mid-1920s expectations on elementary school to provide technological knowledge thus began to be expressed in Svensk Läraretidning, and this could also be seen regarding specific subjects. Since it was a new subject home region instruction was debated a great deal among elementary school teachers ever since the new curriculum was introduced. Each writer wanted to give his or her picture of the subject, and most of the time the historical, geographical and natural science aspects were emphasized. In 1925, however, school inspector E. Westberg also recognized the technical items embedded in the new subject. For example, he pointed to the way the children's own experience and inquiring minds could be utilized in teaching the subject, for instance, when visiting a nearby railroad construction site. At least the boys should be interested in the excavator and its machinery, excavation and tunnelling as well as the making of reinforced concrete constructions. Westberg also viewed the historical items of the subject from a technical standpoint. A study of history would necessarily entail a look at housing, tools and water carriage in former days, which would

\footnotetext{
48 'Kursen i metallindustri och elektroteknik i Västerås', 661-662.

49 J. Paul Grimby, 'En kurs i fysik', Svensk Läraretidning 42, no. 47 (1923): 918.

${ }^{50}$ Sven Nylund, 'Folkskolan och vår tid', Svensk läraretidning 44, no. 30 (1925): 571.

${ }^{51}$ Nylund, 'Folkskolan och vår tid', 571.
} 
make the pupils cherish and even want to develop their own modern houses, tools and water pipes. $^{52}$

Another writer in Svensk Läraretidning, Karl Larsson, addressed technical items in natural science. He argued for a deeper treatment of the different school subjects, due to the rapid development especially within natural science: ‘ . . the teaching in physics and chemistry. To be sure these fields have progressed - just think about the radio - and the teacher must keep up with development so as not to appear too "old-fashioned",53

Educational sloyd changed in a more technical direction in the early to mid-1920s, for a number of reasons. First of all, the curriculum of 1919 meant a clearer focus on handicraft and technical skills, even though the pedagogical aspects were still central. Secondly, leading sloyd pedagogues increasingly emphasized the importance of a solid technical foundation, regardless of the sloyd product: ${ }^{54}$

That the vocational-technical element has received a stronger emphasis in modern ... sloyd is probably in part due to the use of woodworking sloyd in the vocational secondary schools [fortsättningsskola] ... and partly because one wants to meet the requirements of the professional craftsman in some measure; that educational sloyd in that respect should constitute a foundation for craftsmanship, that it should create greater handiness, sense of precision and good technique. Today these skills are necessary to a greater extent than in times past for the craftsman, regardless of trade. ${ }^{55}$

Educational sloyd thus changed both because of internal school reforms in 1918 and 1919, and as a result of new vocational needs in trade and industry.

Thirdly, there was a new aspect that grew in importance after 1920. The influential Swedish designer Carl Malmsten arranged sloyd courses where he sought to develop the

\footnotetext{
${ }^{52}$ E. Westberg, 'Hembygdsundervisningen', Svensk läraretidning 44, no. 36 (1925): 691-2. This history-oftechnology perspective was also comprised by L.G. Sjöholm: 'Klumpiga fingrar III', Svensk läraretidning 44, no. 38 (1925): 734. Even here we find clear references to Dewey, who favoured experiential, practical study of the local environment, the history of its housing and tools in a cross-curricular setting. Westberg's evolutionary view on technology - that a study of history will show how much society and technology have progressed - was similar to Dewey's: Dewey, The School and Society and the Child and the Curriculum, 150-178. Cf. Larry Hickman, 'Doing and Making in a Democracy: Dewey's Experience of Technology', in Philosophy of Technology: The Technological Condition: An Anthology, ed. Robert C. Scharff and Val Dusek (Malden, MA \& Oxford: Blackwell, 2003).

${ }^{53}$ Karl Larsson, 'Ämnesläsning i folkskolan II', Svensk läraretidning 45, no. 31 (1926): 599. Cf. Lars Hofstedt, 'Folkskolans arbetsresultat. Några synpunkter', Svensk läraretidning 46, no. 41 (1927): 798.

${ }^{54}$ Gunnar Thylén, 'Nässlöjden i modärn belysning', Svensk läraretidning 45, no. 33 (1926): 629-30; 'Ur dagspressen. Vid hyvelbänkar och skruvstäd', Svensk läraretidning 45, no. 27 (1926): 530.

${ }^{55}$ Thylén, 'Nässlöjden i modärn belysning', 630.
} 
design aspects of educational sloyd ${ }^{56}$ In the mid-1920s educational sloyd had therefore become partly a new subject, where technology and design items had grown considerably in importance:

Present-day ... sloyd therefore wants to ... satisfy the requirements of the pedagogue as well as the craftsman and the artist. Its purpose is to be a means of developing the child, while at the same time it keeps in touch with its origins, the old domestic arts and crafts, and with the vocational technology of our time. ${ }^{57}$

According to the writer, Gunnar Thylén, elementary school sloyd should be more directed toward 'child technology' (barnteknik), while the sloyd of vocational secondary schools should focus on craftsmanship. ${ }^{58}$

In 1926 and 1927 the National Agency for Education started an evaluation of the 1919 curriculum by sending out a survey to different bodies and organizations. A great majority of the members of the Swedish Association of Elementary School Teachers were of the view that the curriculum was well suited to its purpose. In connection with this evaluation there was a debate in Svensk Läraretidning about the 1919 curriculum and the place of elementary school in society generally. It was also part of an ongoing, broader public debate on the creation of a democratic compulsory school for the children of all classes - bottenskola, enhetsskola - which, in turn, had been engendered by parliamentary investigations of the roles of elementary and secondary school in the whole educational system. ${ }^{59}$

Upon leaving his work as school inspector in the city of Jönköping Robert Johansson delivered a talk on the subject 'Our school problem', which was published in Svensk Läraretidning. In Johansson's view the technification of society had made manual labour almost superfluous. To a great extent steam, gas and electricity had replaced manual labour for the farmer as well as the housewife. However, he did not foresee the complete

\footnotetext{
56 'Ur dagspressen. Vid hyvelbänkar och skruvstäd', 530-31; Hartman, Thorbjörnsson, and Trotzig, Handens pedagogik, 109-110.

${ }^{57}$ Thylén, 'Nässlöjden i modärn belysning', 630.

${ }^{58}$ Thylén, 'Nässlöjden i modärn belysning', 630. Despite the increased importance of educational sloyd - it was, for instance, part of teacher education since 1912 - the subject was still not generally mandatory in Swedish elementary schools, although many local school boards applied for Government funding to make sloyd obligatory for pupils in their own schools: 'Två betydelsefulla utlåtanden av Skolöverstyrelsen. II. Folkskollärare kan icke åläggas att undervisa i slöjd', Svensk läraretidning 44, no. 23 (1925): 456-7; 'Undervisningsplanen för rikets folkskolor', Svensk läraretidning 46, no. 2 (1927): 28-31; Hartman, Thorbjörnsson, and Trotzig, Handens pedagogik, 34, 70-80.

${ }_{59}$ 'Undervisningsplanen för rikets folkskolor', 28; Fredriksson, Hofstedt, and Paradis, Svenska folkskolans historia, femte delen, 136-152, 435-441.
} 
disappearance of manual labour, but rather the need for labourers of a new quality - educated manual labourers: $:^{60}$

The man who ... handles the wheel on a modern excavator must have completely different education than a ... navvy in times past. ... The manual labourers of the future will be mechanics, electricians, assemblers etc. with good comprehensive knowledge [allmänbildning] and thorough professional skill. ${ }^{61}$

Although he acknowledged that different citizens needed different further education, depending on the intended future career, Johansson argued for common elementary education for all citizens. Even though it was not stated explicitly, it is clear that elementary school should provide the comprehensive knowledge (allmänbildning) which was necessary both to handle a technically complex reality and to be able to go on to vocational education. ${ }^{62}$

In the mid-1920s the recently established Swedish radio broadcasting company Radiotjänst began a series of public talks. ${ }^{63}$ One of those talks was a personal evaluation of elementary school and the curriculum of 1919 by Värner Rydén, a very important figure in the Swedish history of education. He was originally elementary school teacher, but had become a social democrat politician and Member of Parliament early on. Rydén was Minister of Education and Ecclesiastical Affairs for a short time in the late 1910s, and then issued the curriculum of 1919 and made the fortsättningsskola obligatory for those who did not go on to other secondary schools. Svensk Läraretidning regarded his speech as very important and consequently published it in its entirety. ${ }^{64}$

Rydén began by addressing the curriculum that he himself launched; it was the beginning of something completely new in the Swedish history of elementary education. Most of all it was the culmination of democratic efforts made in the preceding decades. In a democracy the prime task of elementary school must be general education for all citizens (medborgarbildning). Rydén also listed some other factors that he thought had led to the

\footnotetext{
${ }^{60}$ Robert Johansson, 'Vårt skolproblem', Svensk läraretidning 45, no. 28 (1926): 548; Robert Johansson, 'Vårt skolproblem II', Svensk läraretidning 45, no. 29 (1926): 568.

${ }^{61}$ Johansson, 'Vårt skolproblem II', 568.

${ }^{62}$ Johansson, 'Vårt skolproblem II', 568.

${ }^{63}$ Wormbs, Genom tråd och eter, 23-34.

${ }^{64}$ Värner Rydén, 'Barndomsskolan och det praktiska livet', Svensk läraretidning 45, no. 47 (1926): 926-30; Nationalencyklopedin, keyword 'Värner Rydén', www.ne.se (accessed August 28, 2007). Cf. Thom Axelsson, Rätt elev i rätt klass. Skola, begåvning och styrning 1910-1950 (Linköping: Tema Barn, Linköpings universitet, 2007), 188.
} 
reform of elementary school in 1919, but eventually elaborated on the influence of the technical and economic development in particular. ${ }^{65}$

A farmer, craftsman or businessman could no longer rely solely on the knowledge of his forefathers. He had to keep up to date or succumb in the competition. Agriculture, for example, required knowledgeable and capable practicians: 'The farmer must be able to keep up with the development of his profession, study agricultural literature, have at least the most elementary knowledge of the different branches of natural science ... The same goes for the industrial worker . . . Nowadays each professional needs better schooling than before - this is an inescapable truth. ${ }^{66}$ Although Rydén did not see elementary school as a vocational school the children were too small and the primary task of elementary school was comprehensive education - he yet wanted practical issues to permeate it as much as possible, within the limits of the highly esteemed 1919 curriculum. One such practical subject was educational sloyd: ${ }^{67}$

Some people shrug their shoulders to this subject since children cannot acquire professional skill in, for instance, carpentry during their school days. Those who do that have completely misjudged the issue. It is impossible . . to make children aged 7 to 12 years old into craftsmen.... But ... sloyd develops the hand and the eye ... and gives certain practical skills, which can come in handy in life in various ways. ${ }^{68}$

\section{The Swedish Association of Graduate Engineers (Teknisk Tidskrift)}

The early to mid-1920s was a transition period for technology education generally, which can be seen in the journal Teknisk Tidskrift. As a result of this and the tough labour market the number of pupils in technical education on upper secondary level decreased. Furthermore, technology education on secondary level was far from uniform and there were several overlaps between different more or less functioning school forms. They thus became the object of scrutiny and development work from the National Agency for Education, which followed up the 1918 educational reform of vocational secondary schools and the new regulations concerning technical upper secondary schools of $1919 .{ }^{69}$ In this process there was

\footnotetext{
${ }_{65}^{65}$ Rydén, 'Barndomsskolan och det praktiska livet', 926-7.

${ }^{66}$ Rydén, 'Barndomsskolan och det praktiska livet', 927-8.

${ }^{67}$ Rydén, 'Barndomsskolan och det praktiska livet', 928-9.

${ }^{68}$ Rydén, 'Barndomsskolan och det praktiska livet', 929. The last sentence he also applied to domestic science.

${ }^{69}$ Technical upper secondary schools were divided into two categories in the 1919 regulations; tekniskt gymnasium and teknisk fackskola (the previous teknisk elementarskola continued to exist in some cities, however). Only tekniskt gymnasium gave admission to technical university: SOU 1963:42, 33.
} 
a small but significant shift in the interest shown in technology education on lower levels by writers in Teknisk Tidskrift. ${ }^{70}$

The attention to technology education on the two lowest levels of the Swedish educational system was most often indirect and part of arguments that concerned upper secondary and university level (see Figure 1). However, there is a good deal that can be said about the views of engineers concerning elementary school technology from these arguments. Nils Fredriksson, engineer and head of the Division for Vocational Education at the National Agency for Education, was very active as a writer in Teknisk Tidskrift. He was a member of the Association of Graduate Engineers and the Royal Swedish Academy of Engineering Sciences (Kungl. Ingenjörsvetenskapsakademien) as well as a member of the board of the Royal Institute of Technology. Fredriksson worked hard among engineers to stimulate interest in and debate about technology education on particularly secondary level, as well as to promote a higher degree of cooperation between university level and the different levels of school technology. ${ }^{71}$

In 1927 Fredriksson held a speech at a meeting of the section for teaching of the Swedish Association of Graduate Engineers. After the speech, a debate was initiated by Wilhelm Abenius, principal of the technical upper secondary school (tekniskt gymnasium) in Örebro. This debate was really about vocational secondary schools but mainly came to address elementary technology education. Abenius regarded the technical content of elementary school as very significant for those who wanted to go on to various technical professions, but looked for solutions to the supposedly failed continued technical education just after elementary school: ${ }^{72}$

The young people who leave elementary school at the age of 12 or 13 are physically and spiritually all too undeveloped to be able to enter a practical profession directly. The years after finishing elementary school are lost years for a majority. The knowledge ... that elementary school has imparted to the young people will soon have evaporated. . . . Elementary school must be developed into an eight-year school. In this

\footnotetext{
${ }^{70}$ Julius Körner, 'De tekniska läroverken. Ett diskussionsinlägg', Teknisk tidskrift, allmänna avdelningen 55 (1925): 255; Nils Fredriksson, 'Skolöverstyrelsens utredning angående de tekniska läroverkens organisation I', Teknisk tidskrift, allmänna avdelningen 55 (1925): 419-21; 'Avdelningen för teknisk undervisning', Teknisk tidskrift, allmänna avdelningen 57 (1927): 171; Magnusson, Sveriges ekonomiska historia, 363-370.

71 'Avdelningen för teknisk undervisning', 171; Nils Fredriksson, Vid åttio år. Levnadsminnen 1870-1950 (Stockholm: Tekniska Läroverkens Ingenjörsförbund, 1951), 45-98.

72 'Avdelningen för teknisk undervisning', 171-2.
} 
way the young people would acquire solid knowledge and sufficient bodily maturity for a direct transition to a profession. ${ }^{73}$

Abenius' view was consequently that elementary school should not only be a provider of comprehensive technical knowledge but also a foundation for a technical vocation. Abenius was convinced that an eight-year elementary school was most feasible in cities or industrial communities, because of the close proximity to trade and industry as well as the need to keep young people occupied. Fredriksson, on the other hand, argued that 'an eight-year elementary school was ... desirable but impossible to realize. ${ }^{, 74}$ Abenius' and Fredriksson's views of elementary school technology were thus rather positive, regardless of their differences in opinion. There were writers in Teknisk Tidskrift who were not quite so positive, however. For instance, Rudolf Enblom expressed disdain for elementary school as a basic provider of technology education. ${ }^{75}$

\section{Perspectives on Swedish technology education in the 1920s and beyond}

Regarding the 1919 curriculum it is particularly noticeable that the mechanical sewing machine, an innovation established since several decades, finally found its way into girls' sloyd, while the much newer applications of electricity were added to the natural science curriculum. Gardening, domestic science, drawing and the new subject home region instruction were also to instil knowledge of technical tools, artefacts and processes. There was therefore an increased technical content in the official curriculum document on elementary school in the 1920 s compared to earlier. ${ }^{76}$ This was reflected after a few years in the inservice education that was offered by the National Agency for Education to teachers: courses in industrial metallurgy, electro-technology and electricity. School teachers thus had to increase their knowledge even of technology, which testifies to the influence of the new curriculum, but also to the diffusion of new technologies that affected all of society, including the school. This was a time when modern educational technology began influencing schools, in Sweden as well as abroad. ${ }^{77}$

\footnotetext{
73 'Avdelningen för teknisk undervisning', 171-2.

74 'Avdelningen för teknisk undervisning', 171-2 (quote on p. 172).

${ }^{75}$ Rudolf S. Enblom, 'Till Teknisk Tidskrifts redaktion', Teknisk tidskrift, allmänna avdelningen 58 (1928): 372.

${ }^{76}$ Hallström, 'Elementary School Technology Education in Sweden', 21-26.

${ }^{77}$ Radios, film and slide projectors (epidiaskop) are such examples: 'Våra nya överlägsna projektionsapparater', Svensk läraretidning 45, no. 14 (1926); 'Filmundervisning i alla skolor', Svensk läraretidning 45, no. 37 (1926): 714-5; Stephen Petrina, 'Getting a Purchase on "The School of Tomorrow" and its Constituent Commodities: Histories and Historiographies of Technologies', History of Education Quarterly 42, no. 1 (2002): 75-76.
} 
Around 1920 neither elementary school teachers nor engineers made explicit statements in their journals about the technical status of elementary school. However, the studied stakeholders and their mouthpieces Svensk Läraretidning and Teknisk Tidskrift slowly began to pay attention to an elementary technical domain of knowledge towards the mid-1920s. In the following section the stakeholders' views will be discussed in relation to Layton's (1994) categories and the ideological influences that they represented.

\section{Stakeholders and ideological influences}

To the extent that the professional technologists of Teknisk Tidskrift commented on elementary school it was its relevance for further technical-vocational education or a future technical profession that was focused; engineers were interested in the industrial implications of education. ${ }^{78}$ Their direct interest in and influence on the Swedish elementary school seem to have been small, however. Hence there was a great deal of silence on school issues in the journal, although under the influence of Nils Fredriksson and others this improved in the mid1920s. Class issues definitely played a part in this half-hearted attitude - engineers made up an elite group in Swedish society in the 1920s. Attending to the two highest levels of technology education was a way of keeping a clear distinction between middle- and upper class and working-class technical curricula and knowledge. ${ }^{79}$

Teacher-writers in Svensk Läraretidning, on the other hand, argued that it was comprehensive technical knowledge that was most important, for life after school in general. It should also be pedagogically suited to children - 'child technology'. The creation of the vocational secondary schools in 1918 moved vocational items to these schools, but due to the technification of society and, paradoxically, the new vocational superstructure, the demand for specialized technical knowledge in elementary school yet increased. ${ }^{80}$ Writers in Svensk Läraretidning - Sven Nylund, Robert Johansson and Värner Rydén to varying degrees partly put forward such arguments. Labourers, farmers and craftsmen needed a more thorough generalist and specialist technical education in order to become more competitive in Swedish society in the mid-1920s, and elementary school should provide the fundamentals of this improved education within the boundaries of the 1919 curriculum.

Engineers and some teachers thereby expressed professional technologist and economic instrumentalist ideologies: there was a close association of elementary technology education

\footnotetext{
${ }^{78}$ Layton, 'A School Subject in the Making?', 14.

${ }^{79}$ Goodson, Learning, Curriculum and Life Politics, 75-80.

${ }^{80}$ Many elementary school teachers also taught in the vocational secondary schools.
} 
with both vocation and economic outcome. On the other hand, teachers and engineers also displayed contrary ideological influences in that the former were defenders of participatory democracy and saw technology as a democratizing force, while the latter, more or less consciously, largely ignored elementary school issues and defended their position as a technocratic elite. ${ }^{81}$

The father of Swedish sloyd, Otto Salomon, had seen it as a comprehensive subject. According to Lewis and Zuga (2005), the proponents of the industrial arts subject in the USA in the 1920s - under the influence of Victor Della Vos, Uno Cygnaeus, Salomon, Dewey and others - similarly saw it primarily as comprehensive. However, something in the nature of technology made it open to more than one interpretation of its educational aims, thereby allowing for comprehensive as well as vocational approaches: ${ }^{82}$

This difference in thinking about the purpose of manual training is a difference in thinking that has passed through time because of the very nature of technology and the variety of roles and purposes that technological activity can serve. ${ }^{83}$

The strong industrial impetus in many Western countries in the mid-1920s affected the way one looked at and actually taught subjects such as sloyd and industrial arts. As we have seen, Swedish sloyd went in a more vocational direction in the 1920s, and in American industrial arts 'pre-vocational education' largely became the actual outcome of the previous discussions when entering the 1930s. As a matter of fact, under the influence of economic instrumentalist and professional technologist ideologies the craft-oriented and industrial approach became extremely influential in the few countries that hosted some form of general technology education in the decades to come, for instance, sloyd in the Scandinavian countries, Swedish voluntary technology, craft and design in England and Wales and industrial arts in the USA. ${ }^{84}$

\footnotetext{
${ }^{81}$ Layton, 'A School Subject in the Making?', 13-16.

${ }^{82}$ Lewis and Zuga, A Conceptual Framework, 6-9; Hartman, Thorbjörnsson, and Trotzig, Handens pedagogik, 74-83; Pannabecker, 'Inventing Industrial Education', 15-16, 22.

${ }^{83}$ Lewis and Zuga, A Conceptual Framework, 6.

${ }^{84}$ Lewis and Zuga, A Conceptual Framework, 9; Herschbach, "'What Is Past Is Prologue", 28-34; Zuga, 'An Analysis of Technology Education in the United States', 203-205; Layton, 'A School Subject in the Making?', 13-14; Marion Rutland, 'The Inclusion of Food Technology as an Aspect of Technology Education in the English School Curriculum: A Critical Review', in International Handbook of Technology Education: Reviewing the Past Twenty Years, ed. Marc J. de Vries and Ilja Mottier (Rotterdam \& Taipei: Sense Publishers, 2006), 273275; Marc J. de Vries, 'Technology Education in Western Europe', in Innovations in Science and Technology Education, Vol. V, ed. David Layton (Paris: UNESCO Publishing, 1994), 32-40; Ole Elgström and Ulla Riis, Läroplansprocesser och förhandlingsdynamik. Exemplet obligatorisk teknik i grundskolan (Linköping: Tema teknik och social förändring, 1990), 13-19.
} 
The definition of technology and technical knowledge employed in this article is inspired by recent development in the fields of history, sociology and philosophy of technology. ${ }^{85}$ It helped identify not only comprehensive but also some specialist technical knowledge in a number of the elementary school subjects in the 1919 curriculum. The studied actors particularly the school teachers voiced their opinions in this regard - had a more narrow conception of technology in school, however. When technical knowledge was connected to a school subject it was most often educational sloyd that was mentioned, but occasionally also natural science and home region instruction. Domestic science was not seen as part of a technical domain of knowledge, apart from a brief comment by Rydén. Although in 1930 some $70 \%$ of elementary school teachers were women, the majority of the civil servants of the Agency for Education and the writers in Svensk Läraretidning were men. Women teachers as stakeholders primarily influenced through their own journals. Not surprisingly, therefore, discussions of technology were carried out from a predominantly male point of view, which can also be seen in the discussions on sloyd. ${ }^{86}$

\section{The contribution of educational sloyd}

In a sense one can say that educational sloyd as a subject constituted the most significant precursor to the modern, obligatory Swedish technology subject in compulsory school, given the stakeholders' views and the combination of comprehensive and vocational elements. Kananoja (1994) argues similarly that educational sloyd was the most influential forerunner to modern technology subjects or cross-curricular areas in Sweden, Finland, Denmark and to a lesser degree Norway. The Scandinavian sloyd tradition was very influential as a precursor even in, for instance, the USA, Great Britain, Russia, Argentina, Cuba, Chile and Brazil. However, in these countries the Scandinavian contribution naturally mixed with other influences and consequently did not have the same effect. Even in Sweden it would be wrong to emphasize educational sloyd too much, however. The subject was not made mandatory until 1955 and there was a recognized technical content in other subjects. ${ }^{87}$

\footnotetext{
${ }^{85}$ See cited works for the definition of technology as well as Wiebe E. Bijker, Thomas P. Hughes, and Trevor J. Pinch, ed., The Social Construction of Technological Systems: New Directions in the Sociology and History of Technology (London \& Cambridge, MA: MIT Press, 1987); Leonard J. Waks, 'Rethinking Technological Literacy for the Global Network Era', in Defining Technological Literacy: Towards an Epistemological Framework, ed. John R. Dakers (Houndmills \& New York: Palgrave MacMillan, 2006), 275-280. ${ }^{86}$ Undervisningsplan för rikets folkskolor, den 31 Oktober 1919 (Stockholm 1947), 7-16; Fredriksson, Hofstedt, and Paradis, Svenska folkskolans historia, femte delen, 221, 386-393. Another explanation for the neglect of domestic science may be the fact that it was not part of the regular timetable, but should exist as occasional oneday activities.

${ }^{87}$ Kananoja, 'Technology Education in the Nordic Countries', 45-52; Herschbach, "'What Is Past Is Prologue"”, 30-34; Layton, 'A School Subject in the Making?', 11-12.
} 


\section{Conclusion}

Gradually during the early to mid-1920s there was an increased technical content in the Swedish elementary school, if we look at the new curriculum, in-service education and stakeholders' interpretations and views. The main reasons for this were, first of all, that the first decades of the twentieth century witnessed steady industrial growth, apart from the years directly following the war, with accompanying technification of large parts of society including the school. Secondly, the curriculum of 1919 had a broader technical content than earlier curricula and thus mirrored the societal changes. Thirdly, vocational secondary schools as a new superstructure to elementary school led to new requirements on elementary specialist-technical education, particularly for educational sloyd.

Representatives of the Swedish Government and its Agency for Education were prime movers in enhancing the significance of technology in school, and elementary school teachers readily assisted through inclusion of articles in their journal. Elementary school was to instil comprehensive (allmänbildande) technical knowledge, but, according to several teachers, there was also to be some 'pre-vocational' items due to the changing and more and more technical character of working life. Democratization led to a softening of the conflict between labour and capital, which also led to a somewhat enhanced interest among the middle- and upper-class engineering community in the vocational aspects of working-class elementary technology education. Although it is likely that classroom practice was influenced by these changes future research within the Swedish history of technology education will have to determine the actual effects.

Swedish elementary school technology education of the 1920s in many ways contained the roots of the technology subject today, at least if we look at the current Swedish curriculum. The practical elements inherited from educational sloyd still play an important part and so do natural science aspects on certain items, for example, electro-technology and mechanics. Yet comprehensive aspects have gained ground at the expense of 'pre-vocational' items, and the definition of technology underlying the current curriculum is much broader than technology merely being industrial-practical work or an application of science. The current element of history of technology, which is quite a unique feature from an international perspective, can be traced back to certain interpretations of the home region instruction curriculum. ${ }^{88}$

\footnotetext{
${ }^{88}$ Technology Curriculum for the Swedish Compulsory School, established 2000-07, www.skolverket.se (accessed August 23, 2007).
} 
Today the concept of teknisk bildning is being used by some stakeholders as a Swedish counterpart to the internationally acknowledged 'technological literacy' ${ }^{89}$ In many ways the current situation resembles the 1920s, for instance, the way a democratic and increasingly technological society raises and transforms the demands on, and thereby the content of, technological knowledge in compulsory schools. However, current debates on teknisk bildning focus on a comprehensive, all-round core of technical knowledge, due to rapidly changing technologies and values in a globalized, post-industrial society, rather than on 'prevocational' knowledge.

\section{Acknowledgements}

This research was financed by the Swedish Research Council (Vetenskapsrådet), to which I am grateful for support. I want to thank Thomas Ginner, Jan-Erik Hagberg and the anonymous reviewers for commenting on earlier versions of this article.

\section{Notes on Contributors}

Jonas Hallström is an historian of technology and education. He is currently working at the Department of Behavioural Sciences and Learning, Linköping University, Sweden. His research interests include the history of education, biology and technology education research, history of technology and urban history.

\footnotetext{
${ }^{89}$ See, for instance, Thomas Ginner, 'Törs vi tala om teknisk bildning?', Tekniken i skolan. Nyhetsbrev för teknikämnet i förskola och skola 13, no. 4 (2007): 1-3. Technological literacy is 'the ability to use, manage, assess, and understand technology,' according to the American Standards for Technological Literacy: Content for the Study of Technology (Reston, VA: International Technology Education Association, 2000), 1-10, http://www.iteaconnect.org/TAA/PDFs/xstnd.pdf (accessed September 6, 2006). Cf. John R. Dakers, ed. Defining Technological Literacy: Towards an Epistemological Framework (New York: Palgrave Macmillan, 2006).
} 